\title{
Clinical and epidemiological features on re-emergence of measles in Galati County
}

\author{
Manuela Arbune ${ }^{1,2}$, Liliana Baroiu ${ }^{1,2}$, Gabriela Lupasteanu ${ }^{1,3}$, Lucretia Anghel ${ }^{2,4}$, \\ Anca Arbune ${ }^{5}$, Caterina Dumitru', ${ }^{1,2}$ Alina-Viorica Iancu ${ }^{1,2}$ \\ ${ }^{1}$ Infectious Diseases Clinical Hospital, Galati, Romania \\ ${ }^{2}$ Faculty of Medicine and Pharmacy, "Dunarea de Jos" University, Galati, Romania \\ 3"Ovidius" University, Constanta, Romania \\ ${ }^{4}$ Emergency County Clinical Hospital, Galati, Romania \\ ${ }^{5}$ Clinical Institute Fundeni, Bucharest, Romania
}

\begin{abstract}
The current re-emergence of measles is a serious worldwide public health problem, favored by the decrease in vaccine coverage. Romania is noted for the highest number of illnesses and deaths in the European Union. The study analyzes the clinical-epidemiological characteristics of measles cases hospitalized in a county in south-eastern Romania, where the vaccine coverage with 2 doses of anti-measles vaccine is of $79.6 \%$. We analyzed a number of 221 hospitalized cases confirmed with measles, according to the case definition, characterized by the predominance in unvaccinated infants, from the urban area, frequently diagnosed after the 4 th day of illness, most of them with complicated forms of measles.
\end{abstract}

Keywords: measles, vaccination, epidemic

\section{INTRODUCTION}

Measles is an eruptive disease of childhood, which is very contagious and can be prevented by vaccination. Clinical appearance consists of fever, catarrh, exanthema and specific exanthema (1). The etiology is represented by the measles virus, which has a strictly human reservoir, making it possible to eradicate this disease (2). The transmission is by respiratory tract, with very high contagiousness, estimating that each case of illness will generate another 18 cases of disease, if no preventive measures are taken (3). Measles contagiousness begins 7 days before the onset of symptoms, a period when the virus can spread easily without being detected. As a result, the increase in the number of cases can be exponential. Young age, immunodepression or malnutrition are factors that contribute to increased susceptibility and severe evolution. Migration and free movement of people in remote areas allow the spread of measles virus among different populations of the world (4).

Over 200 million deaths worldwide were recorded annually before the use of the anti-measles vaccine. The systematic vaccination of children significantly reduced measles morbidity and mortality, making it possible to eradicate this disease (4). The effective level of vaccine coverage for the protection of a population must exceed 95\% (5).

Currently, amid the decline in vaccine coverage, the entire world is facing the re-emergence of measles, which is a cause for great concern for public health policies, with priority objectives of intervention of the World Health Organization. The number of cases in Europe has grown steadily in recent 
years. In 2019, Romania ranks first among the European countries regarding both the number of cases $(3,308)$ and the number of deaths ( 5 cases) $(6)$. The reemergence of measles is noticed in all the counties in Romania, including in Galati (7).

In February 2019, the National Center for Statistics and Informatics in Public Health conducted a cohort study of children born in 2013 on the vaccination situation in Romania, demonstrating that vaccine coverage with 2 doses of RRO vaccine at the age of 5 is below the optimal value (95\%) in all counties in the country. The extremes of vaccine coverage were reported in the counties of Satu Mare (maximum 91.7\%) and Hunedoara (minimum 63.4\%) (8). In Galati County, vaccine coverage was of $79.6 \%$, explaining the vulnerability for the evolution of an epidemic $(8,9)$.

The purpose of the paper is to analyze the characteristics of measles re-emergence in Galati County, by evaluating the demographic, epidemiological, clinical and evolutionary situation of the hospitalized patients for measles in the Clinical Hospital of Infectious Diseases of Galati.

\section{MATERIAL AND METHODS}

The study was conducted retrospectively, by analyzing the general clinical observation sheets from 01.01.2016 to 01.12.2019. Cases diagnosed with measles have been identified based on DRG (Diagnostic Related Group) codes corresponding to uncomplicated measles (B05.9) or with different complications (B05.0, B05.1, B05.2, B05.3, B05.4, $\mathrm{B} 05.8)$, which have been reported confirmed according to the case definition (10). All cases were serologically documented, by highlighting antimeasles IgM antibodies. We collected demographic data (age, gender, and living residency), medical history, epidemiological data, clinical and evolutionary characteristics.

The data processing used the descriptive statistics methods, using the SPSS software version (20.0) and the Data Analysis module of the Microsoft Excel program, together with the XLSTAT suite for MS Excel.

\section{RESULTS AND DISCUSSIONS}

Between 01.01.2016 and 31.12.2019, 221 confirmed cases of measles were distributed from the
DRG reports, distributed with seasonal variations, with the highest number of cases in May-June (Figure 1).

The annual weight of measles cases in the Galaţi Infectious Diseases Hospital ranged from $1.4 \%$ to $1.7 \%$ of the total number of hospitalized cases.

\section{Demographics}

Demographic data indicates the predominance of patients in the urban area compared to rural (urban/rural: 149/72), without significant gender differences (male/female: 113/108) and younger than 1 year old $(55 \%)$, but the age has varied from 3 months to 42 years (Figure 2).

The proportion of children under the age of 1 was significantly higher compared to the national situation, in which the largest number of cases is in the age group 1-9 years (Figure 3).

Most infants were born at term (89.3\%), with the average Apgar score $8.5 \pm 1.1[4 ; 10]$ and the average birth weight $3,005 \mathrm{~g} \pm 644$. The average duration of natural nutrition was 6.3 months \pm 6.1 . Chronic favorable conditions for severe measles were mentioned in $10.8 \%$ of infants, specifying heart malformations (3), anemia (3), dystrophy (3), rickets (2), celiac disease (1) and spastic tetraparesis (1). However, these medical conditions were not absolute contraindications for measles vaccination.

\section{Epidemiological data}

Vaccine history was not known in $26 \%$ of cases, especially in adult patients, who changed their residence. We documented the lack of vaccination in $64 \%$ of cases and incomplete vaccination in $10 \%$ of patients (Figure 4).

Diagnosis of other acute conditions preceded $57 \%$ of measles, reporting acute upper respiratory tract infections $(26 \%)$, pneumonia (23\%), gastroenteritis $(6 \%)$, scarlet fever $(1 \%)$ and urinary tract infections $(1 \%)$, for which patients appeared in other medical services.

More than half of the patients were hospitalized prior to the measles diagnosis, especially in the pediatric departments in Galati County or in other counties (Vrancea, Vaslui, Buzău, Braila, Constanta).

Contact with a person with confirmed disease was notified by the epidemiological investigation in $96 \%$ of the investigated cases (Figure 4). 


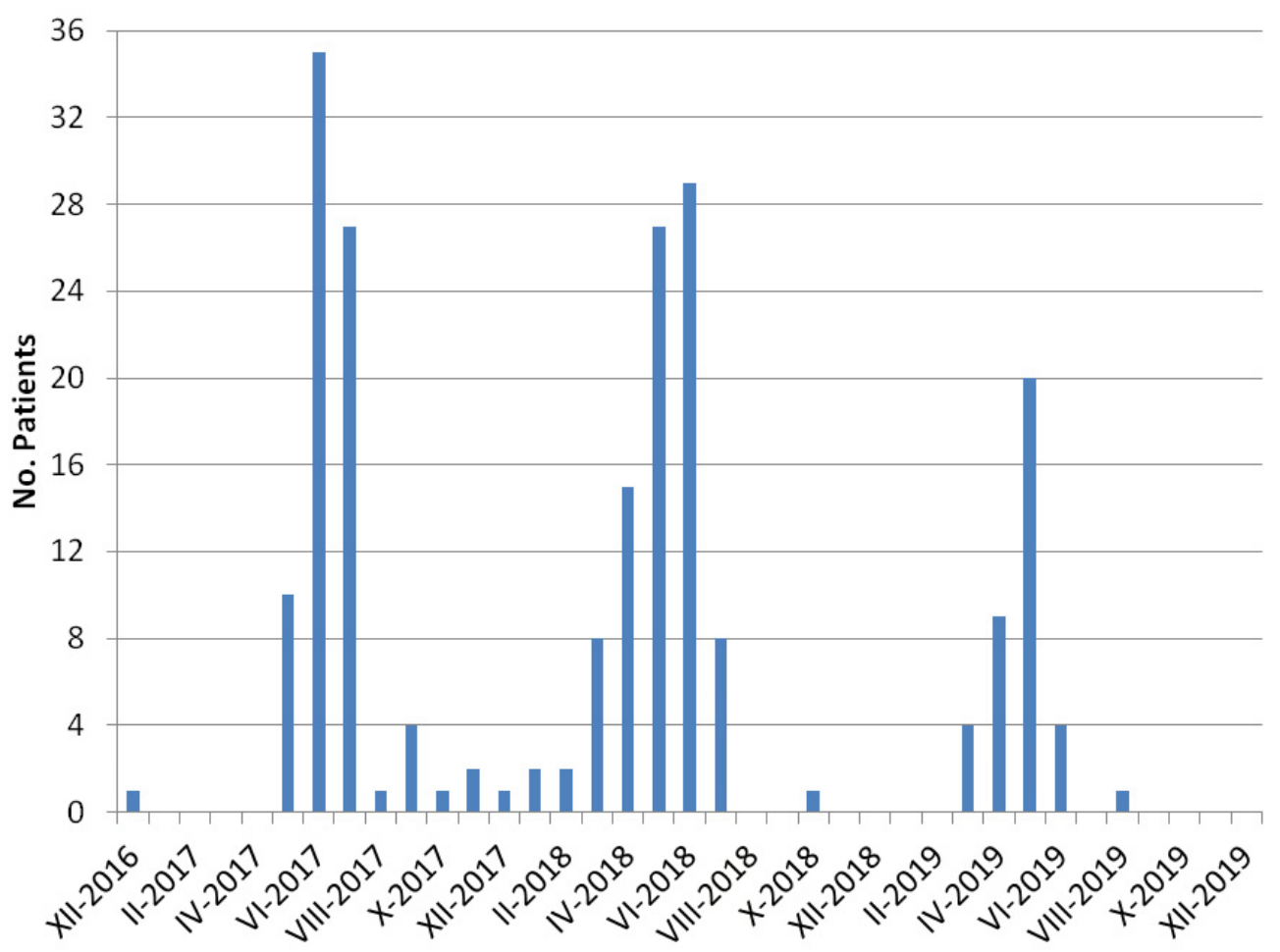

FIGURE 1. Monthly distribution of hospitalized cases with measles

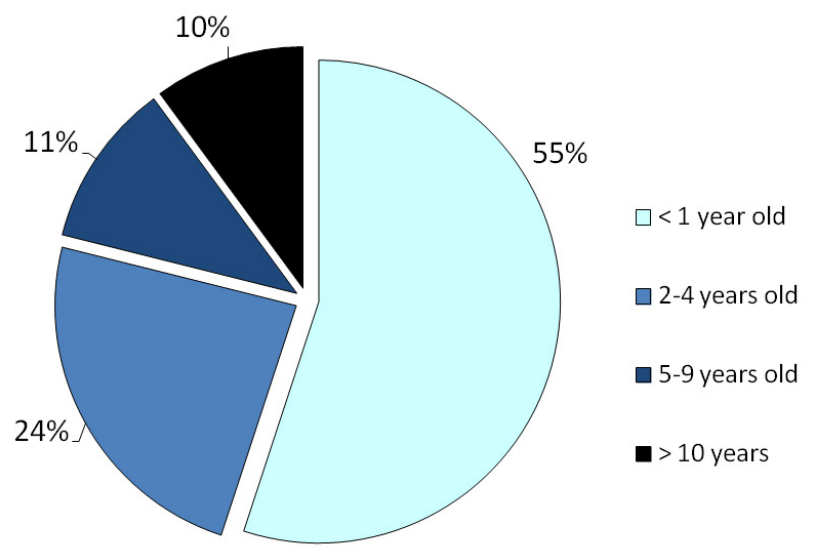

FIGURE 2. Distribution of patients by age at the date of measles diagnosis

In the conditions of the national epidemic, even in situations where the source was not identified, previous hospitalizations for other diseases could have been sources of infection, through contact with cases that were not notified. In addition, hospitalization was associated with the risk of colonization with nosocomial germs and increased risk of measles complications. The use of antibiotics at the onset of measles was reported in $71 \%$ of patients, both in those hospitalized for intercurrent condi- tions and in patients treated at home for pre-eruptional measles symptoms.

\section{Clinical data}

The duration of symptoms from onset to hospitalization ranged from 1 to 12 days, with an average of 4 \pm 1.9 days, indicating delayed diagnosis in most cases.

The eruption is the most important clinical element of measles, but the variable duration from onset to presentation explains the description of different aspects, depending on the evolutionary stage (Figure 5).

The eruption evolved typically, generalized, in $97 \%$ of cases, but there were also $3 \%$ cases with atypical eruptions, which explains the confounding with other conditions and delaying the diagnosis.

Fever was present in $97.8 \%$ of patients during hospitalization, caused by the measles itself or by its complications. The temperature of the hospitalization temperature ranged from $36.8^{\circ} \mathrm{C}$ to $41.3^{\circ} \mathrm{C}$, with the average value $38.7^{\circ} \mathrm{C} \pm 0.9$. The duration of fever ranged from 1 to 9 days, with an average value of $3.6 \pm 2.1$ days.

The Koplick sign is known for its precocity and short duration of expression (12-48 hours), but was 


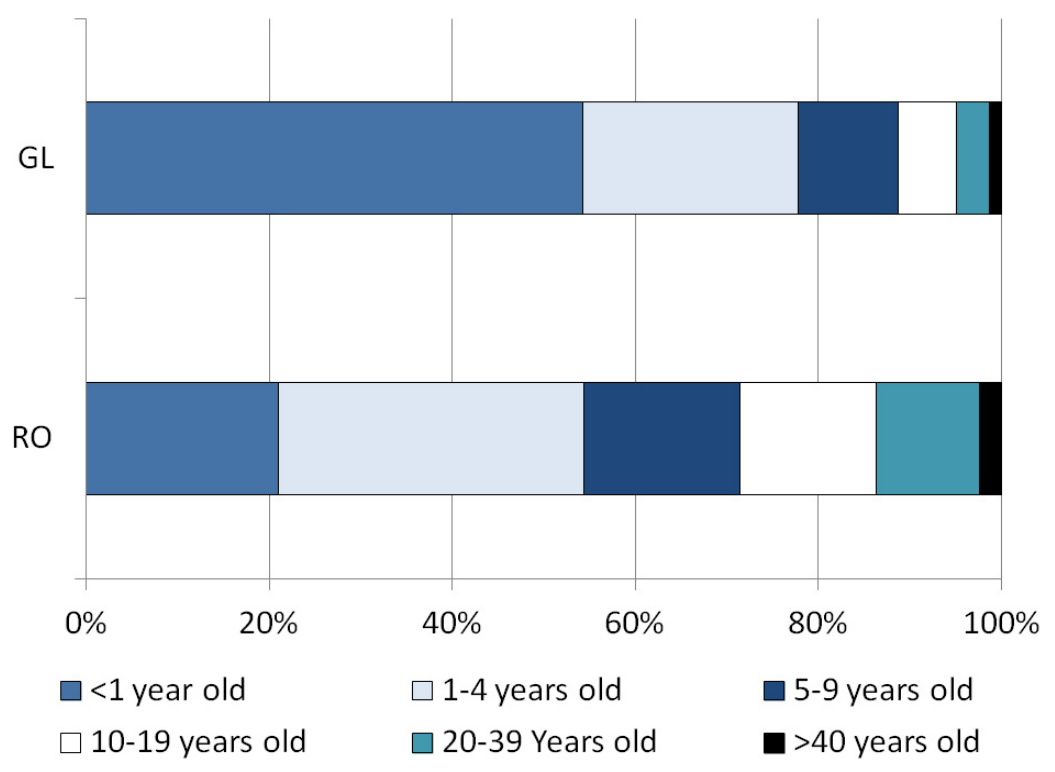

FIGURE 3. Distribution by age groups compared to national data (7)

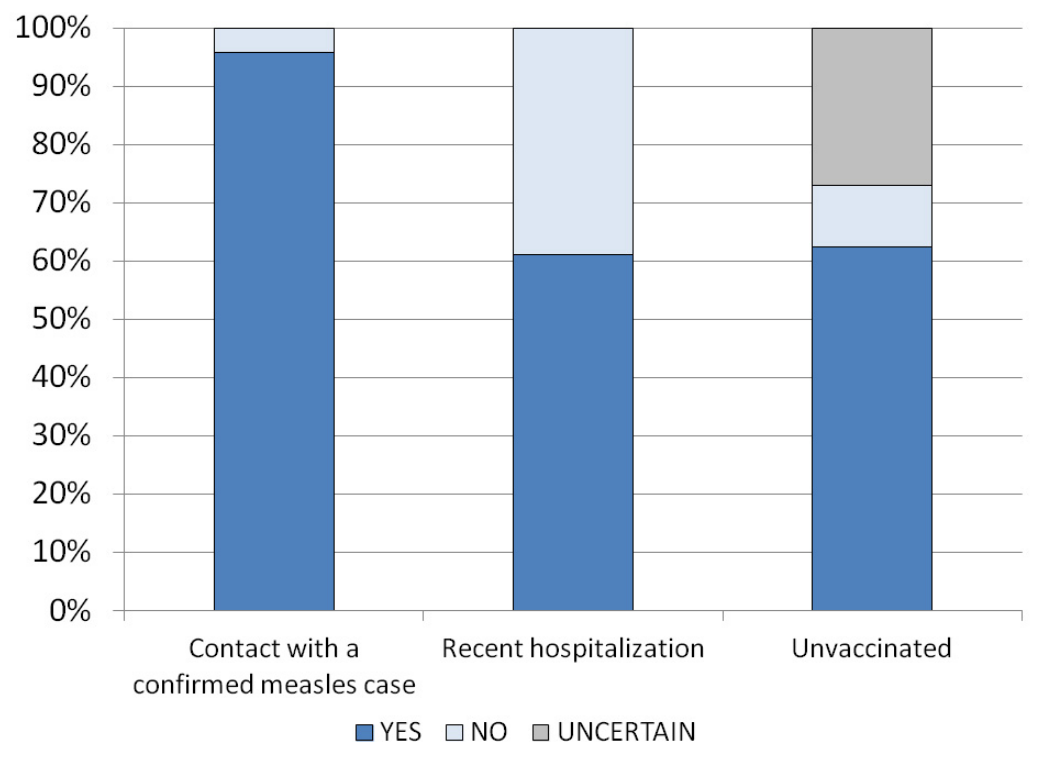

FIGURE 4. Epidemiological risk factors for patients hospitalized for measles

mentioned only in $55.7 \%$ of hospitalized cases, due to the delayed presentation of the patients to the Infectious Diseases Hospital.

The catarrhal symptoms include: ocular localization (conjunctivitis 96.4\%), nasal (rhinorrhea 93.6\%) and bronchial (cough 98.5\%). Cough was productive in $78.5 \%$ of cases.

Other clinical aspects of measles consists in digestive symptoms with vomiting or diarrhea (41,4\%) and neuropsychiatric symptoms, expressed with drowsiness $(66.4 \%)$ or convulsions (3\%) (Figure 6).

\section{Evolution}

The evolution of measles is reflected by the diagnostic code, with the predominance of pneumonic respiratory complications, mentioned in $69 \%$ of cases. Other complications mentioned were acute respiratory failure (9\%), reactive hepatitis (28\%), epileptic seizures (3\%), and infectious nephritis (5\%). We reported two unusual complications, one case of myocardial infarction and another of acute pancreatitis, both of them occurring in women, aged 41 years old and 42 respectively, which clinical recovered (11). 

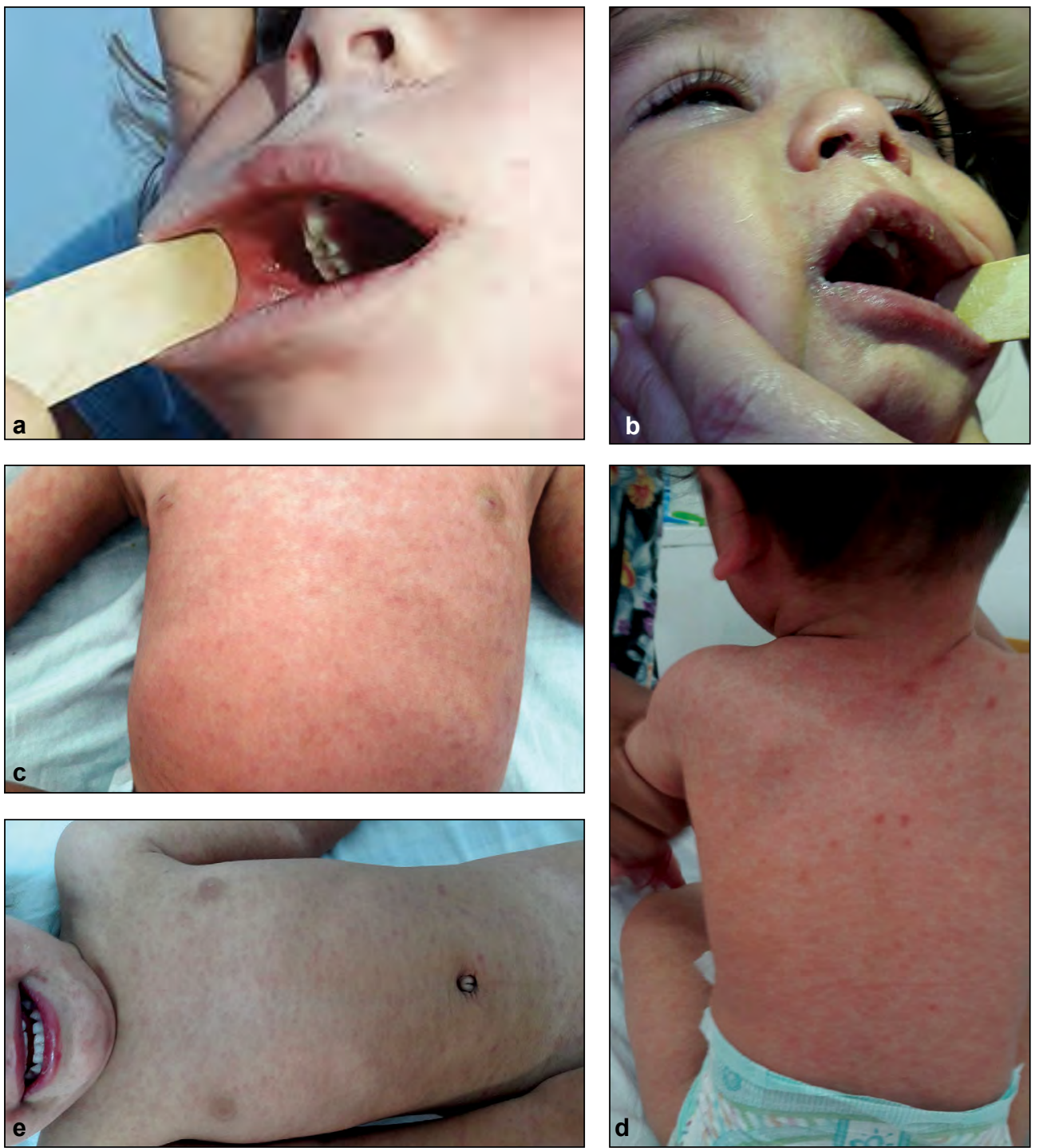

d

FIGURE 5 (a, b, c, d, e). Aspects of measles enanthema and exanthema

There have been no serious neurological complications of measles such as acute meningoencephalitis, but the risk of subacute sclerosing panencephalitis requires ongoing the surveillance, accounting that over the next $10-15$ years it is possible to develop these extremely severe late manifestations.

Only one case was aggravated, a baby who died a few days after he was transferred to an intensive care unit due to worsening respiratory failure and the need for ventilator support, inaccessible in our hospital. The particularities of this case were the urban residency, the male sex, the age of 6 months, the previous lack of evidence of comorbidities. The mortality rate was $0.45 \%$. In the same period, measles mortality at the national level was $0.33 \%$, cumulating a number of 64 deaths, compared to 18,909 cumulative cases during the epidemic (7).
Mild or medium anemia was associated with the diagnosis of measles in $60 \%$ of patients. Liver enzymes, with maximal level of $6.5 \mathrm{x}$ limit of normal value, were explained as measles related hepatitis, but it was also considered the possibility of overlapping drug toxicities accumulated prior to diagnosis, by prolonged use of antibiotics or fever medication.

Patients hospitalized for measles were discharged stationary $(1.5 \%)$, aggravated $(0.5 \%)$, cured $(9 \%)$ or ameliorated $(89 \%)$.

\section{CONCLUSIONS}

The measles epidemic in Galaţi County from the years 2016-2019 had a smaller magnitude than the national average. The measles epidemic is prevalent in unvaccinated infants, from the urban area, 


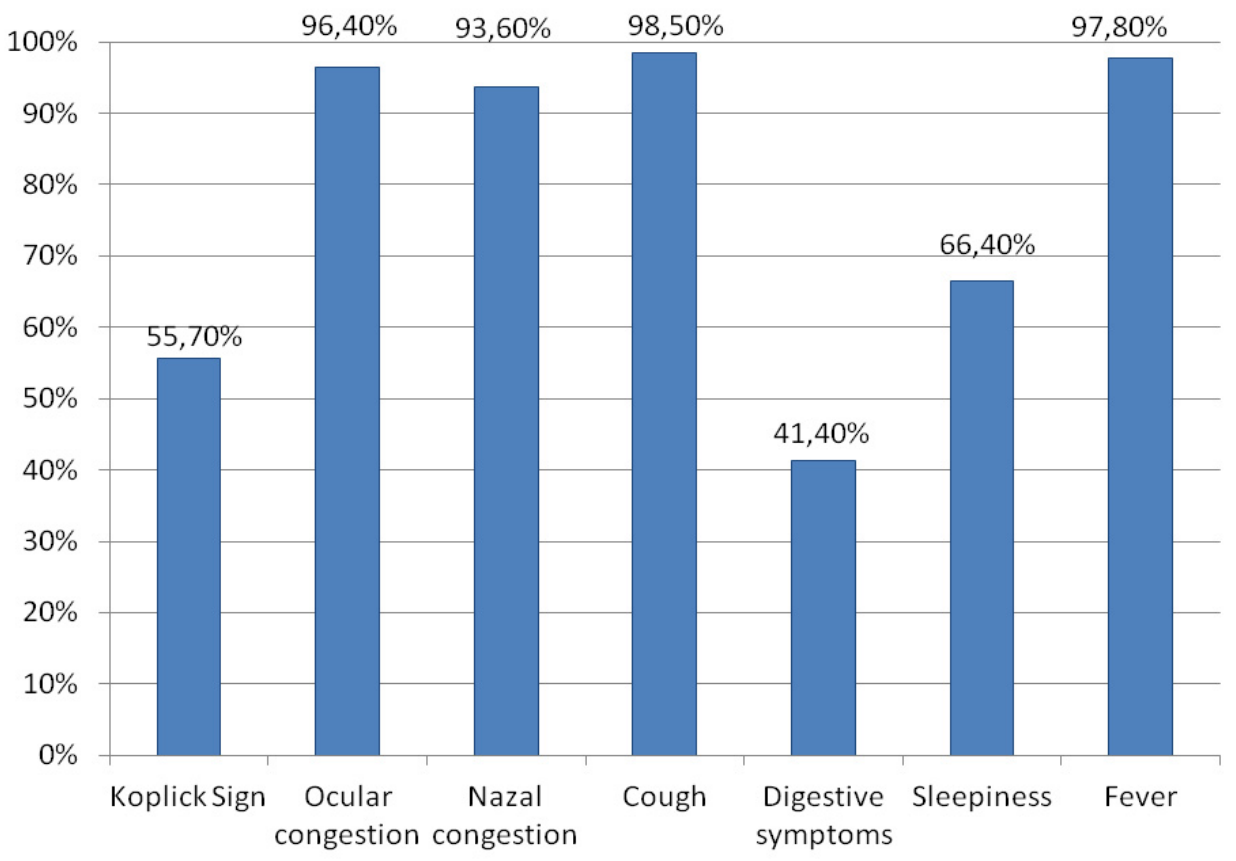

FIGURE 6. Frequency of clinical manifestations in measles

most exposed during hospitalization in pediatric wards for other acute conditions. Pneumonic complications were the most frequent, but the evolution was favorable in most cases of the disease. The long-term prognosis remains uncertain, requiring surveillance for the risk of subacute sclerosing panencephalitis. The re-emergence of measles in $\mathrm{Ga}$ lati is caused by suboptimal RRO vaccine coverage, requiring complex interventions to optimize immunization programs.

Conflict of interest: none declared Financial support: none declared

\section{REFERENCES}

1. Danet C, Fermon F. Management of a measles epidemic: Practical guide for doctors, nurses, laboratory technicians, medical auxiliaries and logisticians, 2013 ed. Geneva: Medecins sans Frontières; 2013.

2. Sniadack DH, Crowcroft NS, (Cantab), Durrheim DN, Rotae PA. Roadmap to elimination standard measles and rubella surveillance. Wkly Epi Record. 2017;92(9-10):97-105.

3. Moss WJ. Measles. Lancet, 2017; 390(10111): 2490-2502.

4. Cousins S. Measles: A global resurgence. Lancet Infect Dis. 2019; 19:362-363.

5. Griffin DE. The Immune Response in Measles: Virus Control, Clearance and Protective Immunity. Viruses. 2016;8(10):282.

6. European Centre for Disease Prevention and Control (ECDC). Communicable Disease Threats Report Week 2, 5-11 January 2020.

7. Centrul Naţional de Boli Transmisibile (CNBT). Situaţia rujeolei în România.

8. Centrul Naţional de Statistică şi Informatică în Sănătate Publică (CNSISP). Analiza rezultatelor estimarii acoperirii vaccinale cu 2 doze RRO la varsta de 5 ani, si cu dt la varsta de 14 ani.

9. Dascalu S. Measles Epidemics in Romania: Lessons for Public Health and Future Policy. Front. Public Health, 2019; 7:98.

10. Comisia Europeană (CE). Decizia de punere în aplicare 2018/945 a Comisiei UE din 22 iunie 2018 privind bolile transmisibile şi problemele de sănătate speciale conexe care trebuie să facă obiectul supravegherii epidemiologice, precum şi definiţile de caz relevante. Jurnalul Oficial al Uniunii Europene, L 170/30.

11. Arbune $M$ (coordonator). Probleme de patologie infecţioasă la frontiere. Volum de rezumate de la Conferinţa Naţională cu participare internatională de Boli Infecţioase "Patologia infecţioasă la frontiere", Galați, 7-9 lunie 2018, Editura GUP, 2018. ISBN 978-606-696-117-2. 